\title{
Orchestral Theatre and the Concert as a Performance Laboratory
}

In the last decade the National Theatre has presented two productions featuring an onstage orchestra (the Southbank Sinfonia) that has been choreographed and made into a key part of the spectacle: Every Good Boy Deserves Favour, by Tom Stoppard with a musical score by André Previn, performed in 2009 and 2010, and Peter Shaffer's Amadeus, performed in 2016 and 2018. Contemporaneously, a vanguard of British orchestras has begun to explore how concerts can be presented in ways that are more theatrically sophisticated than the standard concert format. This article investigates 'orchestral theatre' as an aesthetic proposition by examining the collaborations between the Southbank Sinfonia and the National Theatre, and their legacy in a series of experimental concerts staged by the Southbank Sinfonia entitled \#ConcertLab, which began in 2017. The article aims to identify the artistic and cultural significance of the aforementioned collaborations and \#ConcertLab so as to better understand contemporary efforts to present orchestras (and, more broadly, classical music) in a theatrically innovative manner.

Key terms: orchestras, classical music, National Theatre, Southbank Sinfonia, Tom Stoppard, André Previn, Peter Shaffer, Einojuhani Rautavaara

Something is afoot in the world of orchestral performance. Orchestras are becoming more theatrically ambitious. In the last decade the National Theatre has presented two productions featuring an onstage orchestra (the Southbank Sinfonia) that has been choreographed and made into a key part of the spectacle: Every Good Boy Deserves Favour, by Tom Stoppard with a musical score by André Previn, performed in 2009 and 2010, and Peter Shaffer's Amadeus, performed in 2016 and 2018. Contemporaneously, a vanguard of British orchestras has begun to explore how concerts can be presented in ways that are more theatrically sophisticated than the standard concert format. Groups such as the Southbank Sinfonia, the Scottish Ensemble, Aurora Orchestra, Paraorchestra, and the London Contemporary Orchestra are experimenting with dramaturgy, visual projection, lighting, memorisation, choreography, costuming, audience placement, and audience interaction. This is part of a larger effort to recruit new audiences for classical music and to ensure that the art form does not become culturally moribund or irrelevant - a 'heritage' art form locked into restrictive modes of presentation, out of sync with contemporary artistic development, music performance practices, technological developments, listening habits, and cultural engagement. ${ }^{1}$ However, theatrical experimentation by orchestras is not mere gimmickry or superfluity. Orchestras are exploring how increased attention to 
stagecraft can reveal new aspects of their repertoire, enabling audiences to appreciate music's embodied, intersensorial dynamics, as well as its dramatic potential, uniquely and in a heightened manner.

Orchestras' burgeoning theatrical ambitions suggest the emergence of a new aesthetic for both concert presentation and theatre, or maybe even a hybrid art form in which music is an important, but not necessarily all-determining, part of the performance experience. ${ }^{2}$ Aurora Orchestra refer to experimental projects in which they collaborate with artists from different disciplines as 'orchestral theatre'. This article investigates 'orchestral theatre' as an aesthetic proposition by examining the aforementioned collaborations between the Southbank Sinfonia (SbS) and the National Theatre (NT), and their legacy in a series of experimental concerts. ${ }^{4}$ The NT productions are, generically, examples of dramatic theatre, yet the onstage involvement of an orchestra, written into the script of Every Good Boy and a directorial addition to the NT's 2016 revival of Amadeus, demonstrates the interest of dramatists and theatre-makers in exploring an orchestra's theatrical potential. 'Orchestral theatre' is therefore not the sole province of vanguard orchestras such as the Aurora; fusion of theatre and orchestral performance is undertaken by theatre-makers too.

This article outlines how the collaborations between the Southbank Sinfonia and the National Theatre came about, provides insight into rehearsal processes (acquired from interviews with members of the production teams), and analyses the ways in which the orchestra was incorporated into the presentation of the dramatic fiction. Subsequently, the article examines part of the legacy of these collaborations: a concert series by the SbS entitled \#ConcertLab, which began in 2017. \#ConcertLab advances the SbS's interest in theatrically-minded orchestral performance by experimenting with elements of stagecraft in a laboratory-style fashion. This article aims to identify the artistic and cultural significance of the aforementioned collaborations and \#ConcertLab so as to better understand contemporary efforts to present orchestras (and, more broadly, classical music) in a theatrically innovative manner. ${ }^{5}$ What were the creators of 
these projects hoping to achieve? What do these examples reveal about art forms that have historically had (and can still have) an elitist association? What does it mean to 'think theatrically' about an orchestra in terms of dramaturgy and staging? And how does this relate to musical values and composition?

\section{The Orchestra in Theatre History}

The word 'orchestra' has been part of Western theatre nomenclature since antiquity. In Ancient Greek theatre the orchestra was 'the name given to the circular area where the chorus performed its songs and dances'; in Roman theatre it referred to 'a semicircular space in front of the stage, with seating reserved for senators and distinguished visitors'. ${ }^{6}$ The term was revived near the end of the seventeenth century 'to describe the area in front of the stage where the musicians sat, and was soon extended to the players themselves'. ${ }^{7}$ By the 1790 s and early 1800 s 'the orchestra had become recognizable as the institution that, with changes, still exists in concert halls and opera houses in many parts of the world'. ${ }^{8}$ Wagner famously lowered the orchestra into a sunken pit at

the Festspielhaus in Bayreuth, which opened in 1876. In this arrangement the orchestra was hidden from the audience, thus focusing their attention on the stage and notionally allowing them to become enraptured by the musical drama more easily.

Orchestras of various sizes and configurations regularly provided musical accompaniment for plays in large theatres in London and elsewhere up until the 1930s. ${ }^{9}$ In this respect they played a supporting role in a production, and still do, when present. Occasionally a dramatist will flip the script, so to speak, and write a play about an orchestra (e.g., Jean Anouilh's L'orchestre, first published in 1962, which dramatizes a performance given by a small café orchestra) or about an individual player (e.g., Patrick Süskind's Der Kontrabaß, a monologue given by the character of a disgruntled orchestral double-bassist, first performed in 1981). The premier example of a play that prominently features a symphony orchestra as part of the diegesis (i.e., not 
just providing musical accompaniment) is Every Good Boy Deserves Favour by Stoppard and Previn, which was first performed in 1977 in a production featuring the London Symphony Orchestra and a cast of actors from the Royal Shakespeare Company. ${ }^{10}$ Subtitled 'A Play for Actors and Orchestra', this work has ambiguous genre classification. ${ }^{11}$ Every Good Boy positions the orchestra as onstage performers who can be heard and seen, and who have fictional roles to play in the drama. The latter aspect distinguishes this work from historical examples of theatre and opera in which the orchestra was visible to the audience but was not technically part of the fictional world of the play.

\section{A Play for Actors and Orchestra}

In Every Good Boy a political prisoner named Alexander Ivanov (referred to in the text as Alexander), who lives in a Stalinist regime, is sent to a psychiatric hospital as punishment for political slander (as he maintains). He shares a cell with a character who, coincidentally, shares his name. This other Alexander Ivanov (referred to in the text as Ivanov), described in the stage directions as 'a genuine mental patient', believes that he plays the triangle in an orchestra that is somehow present with him in the hospital. ${ }^{12}$ He talks to and performs with this (imaginary) orchestra, which the audience can see and hear but his cell-mate cannot. As such, the audience is privy to Alexander's 'delusion'. ${ }^{13}$ Stoppard uses this darkly comic scenario to meditate on the theme of fantasy versus reality, the (mis-)treatment of the mentally ill, institutional and state abuse of power, bureaucratic and militaristic absurdity, and the tension between individual liberty and social conformity.

The play was inspired by the Russian dissident Victor Fainberg who, following his participation in a peaceful demonstration against the Warsaw Pact invasion of Czechoslovakia in 1968, was committed to a psychiatric hospital in Leningrad in lieu of a trial, where he remained until his release in 1974. Stoppard writes: 'Mr. Fainberg was not a man to be broken or silenced; 
an insistent, discordant note, one might say, in an orchestrated society'. ${ }^{14}$ A principal player in the 'orchestrated society' of Stoppard's play is the Doctor character, who oversees the 'treatment' of Alexander and Ivanov. The Doctor plays in an orchestra himself, further complicating matters. At one point he goes to play with 'his' orchestra, joining the violinists onstage. This casts the onstage orchestra in a double role: that of Ivanov's imaginary orchestra and a 'real' orchestra of which the Doctor character is a member. As the Doctor is complicit with the political regime, and he plays in an orchestra, the orchestra becomes a metaphor for a pernicious social construction in which regimentation, discipline, and strict hierarchy are key. Previn's score, which has echoes of the work of Russian composers Sergei Prokofiev (denounced as a formalist in 1948) and Dmitri Shostakovich (popularly regarded in the West as a Soviet dissident since his death in 1975), contains dissonant, brassy sonorities and frequently conjures a sarcastic, menacing sensibility. Every Good Boy is by no means a musical caper or a theatrical experiment devoid of substantive thematic content, even if it is laced with Stoppard's characteristic wit and word-play. The score and script combine to create a chilling picture of injustice and hardship, undermining the optimistic refrain offered by Alexander's son, Sacha: 'Everything can be all right!' ${ }^{15}$

Every Good Boy was conceived for the concert stage rather than the theatre. It was first performed at the Royal Festival Hall. Previn, writing in 1978, notes that initially the 'technical problems seemed enormous: where to put the actors, how to design acting areas on a concert stage, how to hide the conductor, how to cope with sight lines, and how to prepare an audience geared to listen to a normal concert'. ${ }^{16}$ According to Previn, they did not manage to have a complete run-through prior to the premiere because of the limited time made available to them in the space. ${ }^{17}$ '[We] felt a bit as though the opening night were taking place on the Titanic, but everything worked'. He continues: 
The principal thing to remember about this piece is its subtitle $A$ Play for Actors and Orchestra. That emphasis is quite correct. It is a play with music and not a symphonic work with words. Whether this rather peculiar and unwieldy form has a future as a concept or whether it was a single attempt is immaterial. The joining of the stage and concert media was thrilling to work on... ${ }^{18}$

As it happens, Every Good Boy did not spark many musical-theatrical compositions of quite the same type. In a way, it is sui generis. But thirty-two years after its first performance it was revisited and reworked. ${ }^{19}$ In a fortuitous development, orchestras had become more open to 'thinking theatrically' and to experimenting with performance possibilities, which made this piece an attractive proposition for revival.

\section{Prelude to a Revival}

The NT's 2009 production of Every Good Boy was a 'happy coming together of lots of things', according to conductor Simon Over, who has been the music director of the Southbank Sinfonia since its formation in $2002 .{ }^{20}$ Under Over, the SbS has sought to present concerts in a readily engaging manner: for example, in their Rush Hour series players talk to the audience about the music on the programme. They might tell them something about why a piece of music matters to them personally and share an anecdote. This type of address is unlike the style and content of traditional music programme notes, which typically provide biographical information about the composer and formal analysis of the music. The players, recent conservatoire graduates, learn about stagecraft, gesture, and physical and verbal communication with an audience early in their year-long fellowship with the orchestra. The aim is to make the players more theatrically aware and, consequently, to improve the experience of live music-making for an audience, who can become disaffected by musicians who appear indifferent to their presence. 
Over had conversations with Nicholas Hytner and Nick Starr, then the artistic and executive directors of the NT, respectively, about the possibility of a collaboration between the NT and the SbS on a theatrically-integrated musical gig of some sort. Every Good Boy was selected as a suitable vehicle, and was thought to be ripe for a fresh staging approach. Tom Morris agreed to co-direct the production with Felix Barrett, the artistic director of Punchdrunk. Both Morris and Barrett are musically inclined, and have learned to play orchestral instruments themselves. Morris says he has long been 'simultaneously engaged and frustrated by live classical music performance' and had 'been looking at ways of trying to integrate classical music with theatrical performance'. ${ }^{21}$ Likewise, Barrett says he has 'been fascinated about what you could do with live musicians in an orchestra in a theatrical environment'; this includes the potential for 'manipulating instruments as character', imbuing an object (i.e., an instrument) with enough potency that the instrumentalist creates a duet, of sorts, with their instrument. 'How do you allow instruments to be other than just devices for sound?' he asks. ${ }^{22}$ Morris and Barrett, both of whom were interested in how an orchestra could be made more theatrically compelling, set out to explore the staging potential of Stoppard and Previn's work, which the original production had largely left untapped. Over and the other musicians were game to experiment with how orchestra players and actors could interact as part of this venture.

\section{Theatricalizing Every Good Boy}

The original production of Every Good Boy, directed by Trevor Nunn, had minimal staging (three small acting areas individually lit, demarcated on a concert platform otherwise occupied by the London Symphony Orchestra). Morris and Barrett's co-directed production for the NT was more theatrically conceived, scenographically complex, and dynamic in its execution. This was a work for theatre, not the concert hall, and it benefited from greater production and financial resources than the original and a much longer period of orchestra rehearsal (about a month). 
Scenes were not confined to acting spaces separate from the orchestra but were played within the space occupied by the orchestra as well. Bob Crowley's set design featured a pathway that jutted through the orchestra, evoking a hospital corridor. [Image 1 near here] The Olivier's drum revolve stage splintered and reconfigured this corridor into shorter paths that ran in multiple directions and sometimes did not join up, depending on the degree of stage rotation. Thus, the set visually represented an unstable and illogical environment. Most of the orchestra was positioned on the revolve stage, and so was part of the scenographic flux. As orchestras usually have a static arrangement, on the whole, with fixed spatial relationships between individual sections and between the players and the conductor, the shifting proxemics resulting from the revolving stage meant that new angles were continually being presented on the orchestra from the audience's perspective (and from the players' perspectives also). The orchestra's configuration and cohesion were visually destabilized, which was appropriate, as in the dramatic fiction the orchestra is ostensibly imaginary; it is a musical hallucination.

The orchestra played multiple roles in this production. Occasionally, they did some 'acting': for example, they collectively clicked their tongues during a scene involving Sacha and his teacher. This action figuratively cast them in the role of Sacha's schoolmates. Additionally, they were made to represent characters symbolically, or, to put it another way, character was projected onto them ('received acting', in Michael Kirby's continuum of 'acting' and 'notacting'). ${ }^{23}$ At one point Alexander gives a speech describing how friends and acquaintances had been terrorized by the state. He refers to them by letter names:

ALEXANDER: My friend, C, demonstrated against the arrest of A and B. I told him he was crazy to do it, and they put him back into the mental hospital. D was a man who wrote to various people about the trial of $A$ and $B$ and held meetings with his friends $E, F, G$ and $\mathrm{H}$, who were all arrested, so I, J, K, L and a fifth man demonstrated against the arrest of E, F, G and $\mathrm{H}$, and were themselves arrested. ${ }^{24}$ 
Individual orchestra members were spot-lit when each of the letter-name characters was mentioned. This complicated the orchestra's symbolic function. Did the orchestra represent the political agitators, the people who have been victimized? Or did it represent the oppressive political regime? Remember that the Doctor, a violinist, is occasionally an orchestra member, and he collaborates with the totalitarian state in his work at the hospital. In this production the orchestra contributed to the onstage play of signifiers. There was more to them than met the eye.

This became especially apparent in an elaborate movement sequence unique to this production (i.e., not scripted by Stoppard), in which a handful of players seized several of their colleagues, pulled them out of the ensemble, and violently 'interrogated' them. The interrogators revealed a KGB-style grey shirt and black tie beneath their formal concert attire. These were actors (dancers), as were the people they interrogated; they had all been 'planted' in the orchestra from the outset and had been miming playing their instruments. The performers enacted a seemingly chaotic, balletic movement sequence (choreographed by Maxine Doyle) in and around the orchestra, involving musicians being manhandled, dragged, and assaulted, and their instruments broken. [Images 2 and 3 near here] The remaining orchestra members (now only constituting bona fide members of the Southbank Sinfonia) continued to play Previn's music, with Over conducting, whilst Ivanov wandered about trying to assist musicians who had been targeted. This sequence featured the orchestra as a place for dancing, as it had been in Ancient Greek theatre. Symbolically, it presented the orchestra as a disharmonious society at war with itself, a restless assemblage of individuals, some of whom were targeting others, with ranks of (innocent? oblivious?) bystanders, all overseen by an authority figure (the conductor) ${ }^{25}$ Furthermore, it suggests that Ivanov 'might have a history connected to the politics going on outside', as Morris proposed in an interview for this article. ${ }^{26}$ In this elaboration of Stoppard's text, Ivanov's mental illness may be considered a symptom of, or a coping mechanism for, trauma he experienced from living in a Stalinist state. 


\section{Is it Live or is it Memorex?}

The directors executed another coup de théatre near the end of the production, cleverly pulling the rug out from under the audience again. One by one, orchestra members rose to their feet and wandered off through a haze of dry ice that had spread across the stage. [Image 3 near here] Over continued to conduct the gradually dissipating orchestra although, puzzlingly, this did not affect the volume of the music. How was this achieved? In the closing minutes a switch had been made from live music-making to recorded playback (and instrumental miming) without the audience's knowledge. In an accompanying, 'impossible' visual image involving the use of a hidden mirror, the pathway on the stage floor appeared to vault upward, beyond the back wall of the theatre, amid a mess of strewn sheet music, overturned chairs, and broken instruments. The audience's senses were doubly deceived.

In an interview conducted in 2018 Over characterized the ending as 'the most challenging aspect' for him and 'perhaps the least convincing thing' about the production. He remarked:

Because I'm so passionate about live music, the fact that we were not playing... we recorded the last three minutes, or whatever... The way the players put their instruments down at this point and walked away so that the whole thing was disintegrating, but the [recorded] music went on. And that's what I struggled with a little bit. If it's disintegrating it should disintegrate, but actually the [recorded] music's carrying on. ${ }^{27}$

Morris was interested to learn that Over remains troubled by this production choice. He offered a different take on the ending: 
Real uneasiness is only achievable when the emotions at play are underwritten by ideology, in my view, and this is a play in which there's an imaginary orchestra onstage. And the point of that staging at the end was that the audience would, for a moment, experience that thing whether you don't know if it's your railway carriage or the other one that's moving. And so the fact that an audience might be invested in the idea of liveness, as Simon [Over] is, helps that. So, that just makes it work, for me, better, because the audience are going 'It's live - it's live - it's live - it's live - it's live - it's live. How can it possibly be live? What? Was any of it live? ... Was it all recorded?' ... In that moment they're in the situation of the character [Ivanov]. ${ }^{28}$

Undermining the audience's confidence in what they are seeing and hearing is fairly common practice in theatre, as is using smoke and mirrors to create stage illusions. This is not common in orchestral performance, however. Concert audiences do not expect theatrical trickery from classical musicians, and the latter are typically devoted to performing music 'respectfully' and honestly (i.e., communicating their interpretation of the score and endeavouring to honour the composer's intentions, or what they understand them to be). The difference of opinion articulated by Over and Morris about the ending of their production of Every Good Boy suggests a subtle clash of artistic values concerning musicality and theatricality; in orchestral theatre, tension can result if one value is seemingly privileged over the other.

Nevertheless, this production of Every Good Boy was a harmonious venture that was a commercial success and critically well-received. Over recalls that the production 'seemed to have quite a profound effect on people'. ${ }^{29}$ He stated, in an interview for this article: 'The players were really affected by the actors, really inspired by them. And the actors were really moved by the live music'. ${ }^{30}$ According to Over, the SbS players felt that they were 'different performers' in the context of this production. ${ }^{31}$ Once the show closed, some of them apparently found it frustrating 
to return to conventional orchestra playing; they missed the freedom and expressivity they had enjoyed in this production. Evidently, orchestral players can get the 'acting bug' too.

This revival of Every Good Boy took an artistic curio - Stoppard and Previn's one-off, hybrid work for actors and orchestra - and re-conceived it for the stage, demonstrating the viability of integrating an orchestra into a production's dramaturgy and mise en scène. In theatricalising the orchestra (e.g., incorporating actors into the ensemble), it made its metaphorical associations and symbolic potential available for (re)consideration. Moreover, its playfulness and openness worked to counter commonly held perceptions of elitism and conventionalism in classical music. In a cultural context of increased 'cross-pollination' between art forms and genres, and continued efforts to engage new and younger audiences (especially for classical music) and combat perceived 'stuffiness', this collaboration between the NT and the SbS - the latter organisation described in the programme as 'Britain's young professional orchestra' (emphasis added) - effectively showcased the artistic merit and cultural value of 'thinking theatrically' about an orchestra. Subsequent projects involving these organisations developed this creative fusion further.

\section{Fast-forward}

Following their involvement in the NT's production of Every Good Boy, which was re-mounted in 2010 after its initial run in 2009, the SbS participated in a semi-staged production of Bach's oratorio St. Matthew Passion in 2011, directed by Jonathan Miller, and in 2012 provided an onstage string quartet for the NT's production of Alan Bennett's play Hymn, a monologue that includes reminiscence about music from the author's childhood. ${ }^{32}$ In 2013 and 2014 the orchestra participated in research and development workshops at the NT Studio on a project (as yet unrealized) about Beethoven that Simon McBurney was devising. Rufus Norris, who was soon to become artistic director of the NT, attended one of the workshops, and was, according to 
James Murphy (then managing director of the SbS), 'captivated by the orchestra'. ${ }^{33}$ Norris enlisted the SbS to perform at the NT's annual fundraising gala in the Olivier auditorium, entitled 'Fastforward'. At this event musicians were individually placed (standing) on the dining tables, in lieu of a flower arrangement; the musicians performed the first movement of Beethoven's fifth symphony from memory as guests arrived. Murphy recalls:

It was a thrilling moment and Rufus [Norris] was enthused about how the orchestra could be further deployed in distinctive ways from the norm. He then put to us the idea of reviving Amadeus with the orchestra at its heart. The NT had no desire to revive it otherwise - the original production still loomed large in audiences' memories - but Rufus felt the orchestra justified a revisit. Though it had been done with a few playermusicians elsewhere, it had never been done with a full orchestra before. ${ }^{34}$

Peter Shaffer's popular play from 1979, a historical fantasy about Antonio Salieri's supposed obsession with, and ultimate destruction of, his 'genius' rival, Mozart (adapted into a hit movie directed by Miloš Forman in 1984), is written as a 'straight' drama. It was not conceived as a 'play for actors and orchestra', like Stoppard and Previn's contemporaneous Every Good Boy Deserves Favour. The play features several short excerpts of music by Mozart and Salieri; in the original NT production this music was mostly provided by recorded playback..$^{35}$ The purpose of including the SbS in the 2016 revival was not merely to provide live music for the production. Rather, the aim was to incorporate the musicians into the dramatic world of the play and its onstage presentation. This had the potential to expand upon what an orchestra can do onstage in addition to playing music.

\section{Rock me, Amadeus}


The twenty players of the SbS who performed in this production did so in ever-changing configurations. Unlike in Every Good Boy, in which the orchestra was kept in standard formation and remained seated for most of the show, in the 2016 revival of Amadeus, directed by Michael Longhurst and choreographed by Imogen Knight, the orchestra operated as a mobile, flexible entity. While the orchestra was sometimes arranged in a traditional format (e.g., positioned in a de facto pit created on the Olivier's stage), it was also assembled idiosyncratically, with small groups of players or individuals variously positioned throughout the playing space. This was an orchestra that was continually on the move, made possible by the players' memorisation of much of the music, forgoing the need for music stands. Reviewers commented on the musicians' movements. In The New York Times Matt Wolf likened the musicians occupying the stage to a 'restless organism that cannot...be stilled'. ${ }^{36}$ Ann Treneman, writing in The Times, referred to the musicians as the 'backbone of the production, scattering and re-forming throughout, like some sort of murmuration of musically gifted starlings' (this simile will be revisited later in the article in relation to Knight's work with the SbS on \#ConcertLab). ${ }^{37}$ Likening an orchestra to an organism and to a group of birds because of the musicians' movements, rather than because of the music they were playing, indicates the orchestra's unconventional but aesthetically significant physicality. Violinists played their instruments on their knees and even lying down, on occasion. A reviewer mentions one of the players 'cat-walking off the stage, twirling a violin'. ${ }^{38}$ At one point a xylophonist managed the tricky task of playing her instrument while it was manually moved across the stage, at some speed, by a pair of stagehands. Talk about dynamic playing! Knight led movement and improvisation workshops with the orchestra, collaborating with them and Longhurst on developing possibilities for their movement scores, which gradually became multi-layered and complex. As Knight explained in an interview for this article, once the players felt confident that their instruments would be safe, and that they would not be asked to do something that went beyond their individual comfort-level, they became increasingly adventurous and willing to experiment. ${ }^{39}$ She would 'feed' them suggestions, like a conductor, 
and they would react according to what each of them was willing and able to do, which turned out to be considerable. Knight was struck by how the musicians would perform actions, as requested, with little or no self-consciousness. '[There was] something very beautiful and very pure about how they would just come on and do whatever [you had] asked them to do', she remarked, adding that one of the things she found exciting was the way in which individuals could suddenly draw focus because of their physicality or movement, unlike in a traditional orchestral set-up where, as Knight puts it, 'nobody sticks out apart from the lead violinist, or whatever' ${ }^{40}$ This production allowed the musicians to display their individuality onstage, perhaps to a greater extent than is customary in orchestral performance, but it also implicated them as figures in Shaffer's drama.

\section{Musicians as Actors and Symbols}

In this revival of Amadeus, members of the SbS undertook 'simple acting', Michael Kirby's term for performance that involves a small amount of simulation, representation, or impersonation. ${ }^{41}$ They acted as supernumeraries in crowd scenes. Moreover, they made physical actions that ostensibly corresponded to Salieri's state of mind, as articulated in his audience asides. For example, in his opening monologue Salieri recalls praying to God and promising to be virtuous should he become a famous composer. As Lucian Msamati, as Salieri, delivered this speech the musicians bowed their heads in silent prayer, making it seem as though they were joining Salieri's entreaty. Later in Act 1, when Salieri delivers an aside about the 'delicious confections' laid out for him and other guests of Baroness Waldstädten, the musicians licked their lips and fingers, furthering a sense of connection between the musicians and Salieri, and in particular his wishes and desires. ${ }^{42}$ In her workshops with the musicians, and during the production run, Knight told them that they should think of themselves as cells in Salieri's body, and that their movements 
and actions should be in direct response to something Msamati as Salieri said or did. ${ }^{43}$ [Image 5 near here]

Interestingly, the musicians' link to Salieri destabilized and their apparent sympathy for him attenuated as his machinations against Mozart were put into effect. At one point the musicians declined Salieri's request to play an excerpt from one of his operas. Evidently, he was no longer in their favour. The musicians' act of 'mutiny' (as Michael Billington described it in his review) might also be thought to reflect Salieri's inner turmoil about his own villainy. ${ }^{44}$ The orchestra's fractiousness might be seen as a visual representation of Salieri's increasingly fractured mental state. When asked about individual, choreographic variance within the collective body of the orchestra, Knight remarked:

We had the idea that the orchestra start as 'the orchestra inside [Salieri] and then they become this monster [that is] against him, but also they become individuals, which in a way is the psychosis. Things about you turn against you - like, 'Oh my God, I thought the drummer was at least on my side'! We wanted to fracture [the choreography] so that it is surprising even for the orchestra, and [for] the orchestra body to then shatter.... They morph into a monster. ${ }^{45}$

The orchestra's choreographic variability, in which an individual player would occasionally appear to 'go rogue' (e.g., the mobile percussionist mentioned earlier) conceivably suggested Salieri's mounting psychological disrepair and his 'monstrosity'. Furthermore, their gradual separation from him may be thought to prefigure his realisation at the end of the play that posterity would celebrate Mozart's music and ignore his own. 'I must survive to see myself become extinct!' he cries. 'Mozart's music sounded louder and louder throughout the world! And mine faded completely, till no one played it all! ${ }^{46}$ 
Shaffer's play is framed by Salieri addressing the audience directly, like the character of Vice in a medieval morality play. Salieri invokes the audience as posterity, as 'ghosts of the future, ${ }^{47}$ In this production the SbS fulfilled the role of musical 'ghosts of the future' by signalling their status as twenty-first century classical musicians. They were dressed throughout the production in formal black concert wear, the default garb of modern classical musicians. During the opening sequence one of the players used their phone to snap a photo of the orchestra as it assembled. In addition to playing excerpts of Mozart's music, the musicians played music especially composed for the production by Simon Slater, which had echoes of Steve Reich (1936-) and Philip Glass (1937-). Slater also gave Mozart’s Symphony No. 25 a club-style remix, adding a pulsating drumbeat to it.

The production emphasized the 'modernness' of both the SbS and Mozart, insinuating a connection between the iconic composer and the ensemble. Mozart, played by Adam Gillen, wore Doc Marten boots and used recognisably contemporary hand gestures (which Knight described as being 'a bit street') along with ad-libbed, modern British slang (in at least one performance Gillen genially asked an orchestra member 'are y'alright?' while exiting the stage). ${ }^{48}$ Gillen cited David Bowie and Johnny Rotten as cultural inspirations for his interpretation of Mozart. ${ }^{49}$ Making Mozart resemble a rock star and aligning him with the SbS in terms of contemporaneity and youthfulness suggested a metaphorical tug-of-war between Salieri and Mozart over the musicians and what they represented: the legacy of an artistic practice. Mozart's victory in this contest was a fait accompli, according to the director Michael Longhurst: 'By having the orchestra onstage, framed as a modern orchestra, you have...the keepers of our music today, and they are the people that Salieri is trying to influence, but...we know as an audience member that it's Mozart's music we listen to and they'll be playing 400 years down the line,.$^{50}$ The NT revival of Shaffer's play presented Mozart (the historical figure), his music, and, by extension, Western art music more generally (though not Salieri's music!), as being culturally 'relevant', despite, or perhaps because of, its 'classic' status. Incorporating the orchestra into the dramatic 
fiction whilst showcasing the $\mathrm{SbS}$ as the latest generation of up-and-coming professional classical musicians aided this mission and served the interests of both organisations, which seek to make 'classic' artworks as well as newly written/composed (or devised) work that is socially relevant, ideally for wide and diverse audiences. Relatedly, Amadeus was part of the National Theatre Live programme in 2017, and so was made available to audiences around the world via cinema screenings (provided one had access to a participating venue and could afford the ticket).

\section{Amadeus in the Twenty-First Century}

As a play that celebrates Mozart's status as a musical genius, touched by God, at the expense of Salieri, who mockingly refers to himself at the end of the play as the 'Patron Saint of Mediocrities', Amadeus contributes to the mythology surrounding Mozart's exceptionality, confirms the cultural cachet of classical music, and buttresses the authority of its musical canon. ${ }^{51}$ Consequently, re-mounting the play in the twenty-first century is not inherently socially progressive or challenging to the cultural status quo, even if a scene in which Salieri propositions Constanze, Mozart's wife, with a promise to advance her husband's career resonates with the \#MeToo movement. Shaffer's play, written in the late 1970s, does not register efforts to dismantle the stranglehold that select male, white composers have had over the canon of

classical music and, consequently, over who 'represents' the art form in the popular imaginary. ${ }^{52}$

However, casting the British-Tanzanian actor Lucian Msamati as Salieri symbolically acknowledged the involvement of musicians of colour (historically overlooked and disenfranchised) in Western art music past and present, even if the historical Salieri was white. Indeed, the cast was notably more diverse than in the original staging. In addition to Msamati, the cast also featured other actors of colour, namely Sarah Amankwah and Hammed Animashaun, who played the Venticelli (Salieri's informants), and Karla Crome who played Constanze. Moreover, there was cross-casting of sex: Alexandra Mathie played Count Johann 
Kilian Von Strack. Alas, the diversity of the SbS players involved in both the 2016 and 2018 runs of this production was not as evident as that of the acting company: whilst the musical ensemble was balanced in terms of the number of men and women, it was still majority-white. This may speak to the under-representation (and disadvantaging) of black and minority ethnic people in classical music education/conservatoire training as well as corollary under-representation in art and the media. ${ }^{53}$ Perhaps seeing Msamati as Salieri will have encouraged young people of colour to imagine themselves as classical musicians, even if Salieri's role in Shaffer's drama is as a villain who plays second fiddle to Mozart. ${ }^{54}$

\section{\#ConcertLab}

Following their successful collaboration with the NT on Amadeus, the SbS has continued to 'think theatrically' about orchestral performance. 'After [Amadeus] opened', stated former managing director James Murphy, 'I vowed that it wouldn't be an end in itself but we'd see what we could do to transplant some of its spirit back to the orchestral world' ${ }^{55}$ In 2017 the SbS launched \#ConcertLab, a series of concerts that experiment with how orchestral music is programmed and performed. The creative team of the SbS took inspiration from the rehearsal process for Amadeus. Matt Belcher, communications director of the SbS and creative director for \#ConcertLab, sat in on a rehearsal for Amadeus and noted the exploratory, open-ended way in which Longhurst and Knight worked with the orchestra and the actors. This, he observed, was quite unlike a regular orchestra rehearsal, which is usually highly regimented and more strictly goal-oriented and time-constrained. Belcher was struck by the 'totally different way of thinking about the artistic product, where the journey was as important as the outcome $\cdot{ }^{56}$ Could this approach, with its spirit of research and development, be used in the preparation of orchestral concerts too? 
The SbS's brochure for its 2017 season introduces \#ConcertLab with the following provocation: 'Classical music is boundless, yet concert presentation has hardly changed in 200 years. What if we're missing out on something? ${ }^{57}$ The 'something' that audiences might be 'missing out on' is the full theatrical potential of live orchestral music, which has traditionally been under-utilized and made subsidiary to staid cultural conventions (including behavioural etiquette) and questionable ideas about music. Although 'musicking' (to use Christopher Small's term for making or attending to music) is an inherently embodied, multi-sensory activity that is enlivened by the dynamic co-presence and mutual regard of performers and attendants, this has not always been recognized, or deemed of primary importance, with respect to Western art music. ${ }^{58}$ Simon Shaw-Miller encapsulates a way of thinking about 'classical music' as autonomous, abstract sound, which derives from the Romantic idea of 'absolute music' and is still prevalent: 'Classical music is an art of sound where anything that might distract from "the music", the sound, is silenced; image is not important, dress is uniform, not individualistic. Most defiantly, theatricality and spectacle are not allowed to take precedence over "musical" values'. ${ }^{5}$ Shaw-Miller and other scholars have outlined the small-mindedness and, indeed, wrongheadedness of this philosophy, which has contributed to the tradition of formally conservative, presentationally routine concerts in which there is relatively little variance in how music is performed and received. ${ }^{60}$ The SbS's \#ConcertLab series eschews what may archly be called the 'deadly theatre' of standard orchestra concerts (to borrow a phrase from Peter Brook) and instead investigates newfound theatrical possibilities of orchestral music-making. ${ }^{61}$ As Murphy asks, 'what in the score of a piece of music dictates how it should be staged?' ${ }^{62}$ Orchestras theoretically have ample freedom with regard to how they present a piece of music, especially work that is in the public domain (i.e., not subject to licensing approval by a composer or a composer's estate). The SbS explores this relatively uncharted artistic territory via \#ConcertLab, which, at the time of this writing, is in its third year of operation. 
In the first season of \#ConcertLab, in 2017, the SbS presented eight concerts at their base of operations in St John's Church, Waterloo. All but one of the concerts was free to attend. The concert series was produced using a fairly modest budget and time-scale (relative to the NT's production process). Each of the concerts was framed around exploring a particular aspect of stagecraft or theatricality and sought to gather relevant data on one or more of the following research questions (as set out in a report for the Royal Philharmonic Society):

- When does a concert experience begin?

- How might the musicians set the scene for the drama ahead?

- How might the audience-orchestra relationship change to make a more immersive experience for both?

- What role could concertwear have in concerts?

- Could [performer] movement help convey more of the boundless spirit in orchestral music?

- How might atmospheric lighting enhance the power of a performance? ${ }^{63}$

The SbS experimented with performance variables, such as audience proximity and placement (including positioning audience members within the orchestra); allowing performers to choose items of clothing that they felt matched the 'colours' and moods of pieces of music; and using light to 'act as an extra instrument in the orchestra, never eclipsing the music but providing a sensitive accompaniment' (à la Adolphe Appia). ${ }^{64}$ The musicians participated in R\&D-style workshops for these concerts and collaborated with designers and movement specialists uncommon practice for an orchestra.

The title of this concert series alludes to the idea of a laboratory, which suggests a process of experimentation and testing ideas. According to \#ConcertLab's creative director, the orchestra and its creative team learn as much, if not more, from concerts that do not go entirely according to plan, or that prompt 'resistance' from players, conductors, and/or audience 
members. Conservatoire-trained musicians will not necessarily appreciate the importance of theatrical lighting, for instance, especially if the lighting complicates their ability to read sheet music. If they are asked to memorize music, they may think this is sufficiently impressive and may not wish to do anything else that is out of the ordinary in a particular concert. Musicians will often not have uniformity of opinion about the clothing they should wear onstage and may have internal conflict about the degree to which they can, or should, move expressively in response to the music as they play. Nevertheless, as the players gain experience of participating in \#ConcertLab and getting positive audience feedback, Belcher notes that they become more willing laboratory participants.

A structural challenge for the orchestra's creative team is the fact that each year there is a new roster of musicians, as the orchestra operates an annual fellowship scheme. Consequently, the experience and knowledge that the players acquire in theatrically experimental concert performance does not carry over from year to year. The musicians have to learn what it means for an orchestra to 'think theatrically' from scratch, and come to appreciate why this approach to concert performance is worthwhile. Unsurprisingly, some players are more enthusiastic about this venture than others. Most of the musicians will not have been extensively trained in stagecraft (certainly not as much as actors), and may have limited experience with improvisation and devising. Most of them will not have been asked to memorize orchestral scores before, or to perform them in a non-traditional manner. Most will not be accustomed to moving in performance, beyond the usual physical requirements of playing their instrument; being dressed in unconventional attire (in the context of orchestral performance); playing under strong or variable lights; or, indeed, participating in an exploratory, creative process in which the outcome may not be totally determined until the day of the performance. \#ConcertLab pushes classical musicians out of their comfort zones by encouraging them to explore the brave new world of 'orchestral theatre'. Audiences are likewise challenged, or enabled, to experience orchestral 
repertoire uniquely, as music that a composer may not have intended to be 'staged' is given new, theatrical lease of life.

\section{Cantus Articus}

One of the standout presentations of the 2017 \#ConcertLab season was a performance of Finnish composer Einojuhani Rautavaara's 1972 work Cantus Articus: Concerto for Birds and Orchestra, which featured as the culminating piece in a concert conducted by Maxime Tortelier themed around the idea of motion in nature. Jean Sibelius's tone poem Scene with Cranes (1906, based on incidental music for Arvid Järnefelt's 1903 play Kuolema (Death)) and Toru Takemitsu's 1988 work for chamber orchestra Tree Line were the other items on the programme. Imogen Knight, who had worked with the orchestra on Amadeus, was invited to serve as movement director for the concert, and specifically for the Rautavaara. Knight led the orchestra in a series of preparatory workshops/rehearsals in which she and the musicians explored how the piece might be presented in a choreographically mindful fashion. As stated in the orchestra's report to the Royal Philharmonic Society:

Notably, this [process] did not comprise choreographic steps imposed by Imogen. Instead, workshop days ahead of the June concert enabled the players to establish what they might be able to do physically whilst performing the work. This presented a wholly new way of working. Even with Maxime [Tortellier] present, gone was the traditional hierarchy of a conductor directing the piece; instead, every player had a voice. Ideas were road-tested, rejected, refined; players challenged each other to see how far they could go. ${ }^{65}$ 
What was not included in the orchestra's report was that the musicians were 'totally bemused' at the beginning of the process, according to Matt Belcher. ${ }^{66}$ Knight explained that she initially got the musicians to dance to Rihanna and sit around in a circle explaining why they played their instrument - atypical activities in an orchestra rehearsal! Initially, players were slightly resistant to Knight's request that they memorize the music, which is about fifteen minutes long; ultimately they memorized $90 \%$ of it, Belcher estimates. Over the course of six three-hour rehearsals Knight and the musicians fashioned a movement score that exploited the possibilities offered by the space available in St John's Church. Knight had to work within the constraints of maintaining a sightline for the conductor and certain players at specific points in the piece and ensuring that instruments were protected and musicians felt comfortable about what they were doing. The orchestra only managed one complete run-through before the first performance. Would this experiment work? The players were not fully confident that it would, Knight recalled. They were being asked to depart from standard orchestral operating procedure and do things unimagined and unprescribed by the composer.

The three pieces on the programme for the SbS’s 'Motion' concert on June 8, 2017 were presented in a continuous sequence, reinforcing their thematic connection. Flickering, fluorescent floor lights scattered around the nave and altar areas of St John's Church created an eerie atmosphere, Belcher noted. ${ }^{67}$ At the end of performance of Sibelius's Scene with Cranes, players not involved in the Takemitsu (but who would return to play in the Rautavaara) knocked over their music stands, strewing sheet music on the floor. The orchestral apparatus had begun to deconstruct; its formal rigidity was unsettled. Music stands were again turned over after the performance of Takemitsu's Tree Line. And so the visual setting for Cantus Articus was, as Belcher describes it, an 'apocalyptic floorscape' of overturned music stands and sheet music. ${ }^{68}$

Freed from their stands, and with the music mostly memorized, the musicians were able to perform Rautavaara's piece in a novel fashion, using their bodies, moving and still, to create visual scenes that animated Rautavaara's score, effecting a heightened musical-theatrical 
experience. [Images 6-9 near here] The musicians' movements were not intrinsically complex, formally refined, or showy. They were not attempting to perform physical theatre or dance, as such. This is not their training. Knight related, in an interview, that she is not interested in creating 'impressive' movement for the sake of it, or in attempting to make orchestral musicians into acrobats with instruments. Rather, she appreciates the 'purity' and 'rawness' of the musicians' untrained physicality and respects their hard-obtained musical skills. She strove to highlight these features and 'honour' the ancient act of performing and listening to music in a shared space. ${ }^{69}$

\section{Scenes from a Theatrical Concert}

The players are positioned at the back of the church and on the balcony. They tune. The musicians at ground level slowly drop to the floor and lie there. The bassists and cellists, seated, flop over their instruments. The musicians in the balcony drape themselves over the railing. The conductor, sitting on a step near the altar, conducts with one hand, his head bowed. Two flautists standing on the balcony begin playing.

The conductor stands and inches forward. The harpist guides her instrument, on wheels, across the floor of the church. The cellists and bassists rise. They slowly come forward in a line, carrying their instruments proudly before them. They carefully avoid the floor hazards and seat themselves.

Violinists, lying prostrate, collectively rise, like the dead coming to life. They walk as they play, 'flocking' near the conductor. During a passage in which they have nothing to play, they gently sway.

The orchestra is silent. Recorded bird sounds are heard. The conductor centres himself in a cluster of string players. They look up and they sway, listening to the plaintive song of the shore lark. It is a delicate scene, ghostly and beautiful. 
Woodwind and brass players join the throng. The conductor, now standing on a chair, conducts from the centre. The orchestra has flocked to bim.

One musician lies 'dead' on the floor. The ensemble turns to look at her. They freeze.

The conductor leads a band around the space, like the Pied Piper. Moving slowly, musicians follow bim, single line. Two players, free of instruments, make darting movements across the mess of overturned music stands and interspersed floor lights. There are bodies moving at different speeds and intensities.

A percussionist stands on a chair and crashes together a pair of cymbals. The musicians come to the centre of the space and sink to the floor with their instruments. The bird sounds taper off. The final chord and percussive sound reverberate. The lights go out. Everyone and everything lie strewn.

A long pause, followed by enthusiastic applause and whooping. ${ }^{70}$

\section{A Murmuration of Musicians}

Although the movement score of this performance of Cantus Articus was not especially complicated, it nonetheless facilitated a new way of experiencing and interpreting the work. To be clear: there are no instructions in Rautavaara's score pertaining to the players' physical arrangements or movements. The score only provides instruction about the notes the musicians should play and the manner in which they should play them, along with instruction concerning playback of recorded bird sounds. Of course, there is also nothing in the score that prohibits or invalidates the 'staging' of the music in the manner undertaken by the SbS; presumably, this is not something Rautavaara imagined as a performance possibility in 1972. 
Performing this work using specialized scenography (e.g., the upturned music stands and floor lights), choreography, and dramaturgy (e.g., the thematic linking and joining-together in performance of the three pieces in the programme, in addition to the deconstruction of the orchestral apparatus over the course of the concert) added new dimensions to the work. The staging was not a gimmick. It did not prevent the musicians from performing Rautavaara's score precisely and sensitively. On the contrary, it arguably enhanced the emotional and spiritual power of Rautavaara's music by giving it a visual and kinetic analogue that was timely and resonant. Knight said, in an interview, that the use of recorded birdsong in the composition put her in mind of a world in which birds are extinct and their vocalisations are only preserved in recorded format. ${ }^{71}$ She thought of birds covered in oil. This cast the piece in an elegiac light. The SbS's performance of Cantus Articus could be registered as an environmental warning: a reminder of the damage caused by human exploitation of natural resources and the disruption of habitats and migratory patterns resulting from climate change. Alternatively, the spectacle of groups of people raggedly moving together, journeying forth, sinking to the floor, and lying supine was also suggestive of the European migrant crisis, images of which were widely shared in the media at the time of the performance. The musicians were not pretending to be birds or refugees, or anything in particular. They were not acting, yet they were using their bodies to play (in) the space, rendering it a zone of imaginative possibilities and carefully crafted sonorities. Neither the ecological nor the migrant concept was straightforwardly imposed on the piece. This would have delimited its meaning. Rather, the staging made these and other associations available for consideration, opening up new perspectives on Rautavaara's work decades after it was first composed and performed.

The audience response to the performance was highly favourable. Composer/performer Anna Meredith posted on Twitter: 'blown away by an amazing memorised \& movement-y Rautavaara performance by @SouthbankSinf last night - goosebumps galore'; she humorously followed this text with five duck emoticons. ${ }^{72}$ Belcher privately referred to the performance as 
'the most moving orchestral experience I've seen'. ${ }^{73}$ The SbS performed the concert twice in the same evening. After the first concert Knight said the musicians realized the staging approach was successful, and so they were 'pumped' about performing it again. 'I think they suddenly realized that they had permission to be who they were, and [that] it was a special performance', she commented. ${ }^{74}$ After the second concert the audience refused to stop clapping upon the musicians' departure, requiring her to bring them back for another bow. She recalled that players who had not spoken to her during the rehearsals approached her afterward and told her that the experience had changed their life, and that they had never done anything like it before. 'This is why I really want to do this work' (i.e., collaborating with orchestras), Knight remarked, as 'it not only makes classical music open to more people because it doesn't put it in a traditional format... but it opens it up to the musicians as well, and they learn a thing about themselves that they maybe never learned before'. ${ }^{75}$ 'Orchestral theatre' can be revelatory for all involved; moreover, it can make the art form more appealing to new and younger audiences.

\section{Future Classical}

Audiences for \#ConcertLab typically comprise a younger demographic, according to its creative director. ${ }^{76}$ Unsurprisingly, an older demographic is more likely to attend conventionally staged concerts featuring the work of canonical composers. How long can the classical music industry sustain the model of conventionally staged concerts as the norm? Belcher thinks there will always be a place for such concerts, but hopes the experimentation exemplified by \#ConcertLab will become more widespread. ${ }^{77}$ Indeed, this may be a necessity if the tradition of live orchestral performance is to thrive. There is already a trend, since the early 2000 s, of performing classical music in non-traditional venues (e.g., nightclubs, 'found' spaces); this can facilitate a looser, more relaxed, and perhaps more sociable or participatory mode of audience engagement than that 
which is commonly associated with a purpose-built concert hall. ${ }^{78}$ This parallels the interest of contemporary theatre-makers and audiences in site-specific, or site-responsive, theatre.

Theatre-makers, designers, and choreographers will, hopefully, continue to be part of the future development of orchestral performance in theatre and elsewhere. Reflecting in 2019 on the NT’s 2009 production of Every Good Boy, co-director Felix Barrett commented that, in his opinion, the way in which the orchestra was used in this production was still fairly conventional and that the players were not pushed out of their comfort zone as much as they might have been had the circumstances (e.g., the performance space) been different. He says he only accomplished a fraction of what he wanted to achieve. The aspects of the production he considers interesting and of which he is proud (such as the dancers masquerading as musicians, and the switch between live and recorded music at the end of the show) are, for him, creative 'itches' concerning music performance that he still hasn't fully 'scratched'. He continued:

I want to be the audience member standing inside the orchestra. What is that going to sound like? That's the first step. And once you've got that, that's basically the equivalent of doing a promenade play where you go from room to room.... What's the version where you change the performance language, where you use illusion...visceral triggers... I don't know what that is, but I still want to try and find out. ${ }^{79}$

What will the 'performance languages' of orchestral music be in the future? And to what extent will they borrow from theatrical staging techniques?

This article has analysed artistic experimentation in the use of an onstage orchestra in theatre and has connected it to recent, innovative staging practices involving orchestral musicians, theatre-makers, and artists from other disciplines. This area of artistic activity, which has previously been unexplored in theatre scholarship, promises to have increasing cultural relevance. The collaborations between the National Theatre and the Southbank Sinfonia on 
revivals of Every Good Boy Deserves Favour and Amadeus indicate continued interest among theatremakers in theatricalising the orchestra and incorporating it into dramatic fiction. \#ConcertLab, which is part of the legacy of these collaborations, illustrates how vanguard orchestras are experimenting with the theatrical possibilities of musical performance. This article has begun the process of theorizing and historicizing 'orchestral theatre' by focusing on a particular body of work, and has argued for the artistic and cultural significance of 'thinking theatrically' about an orchestra. Excitingly, there is much more thinking to be done on this topic by artists and scholars alike.

\section{Notes and References}

${ }^{1}$ See Susanna Eastburn, 'Is Classical Music a Living or Heritage Art Form?' in Chris Dromey and Julia Haferkorn, eds., The Classical Music Industry (New York: Routledge, 2018), p. 141-7.

2 James Murphy, chief executive of the Royal Philharmonic Society, stated in an email sent to the author on 5 October 2018: 'I feel maybe we're at the frontier ... of possibly a new sort of hybrid art form, or certainly being freer in the way we present extant ones'.

${ }^{3}$ See: https://www.auroraorchestra.com/our-work/the-orchestral-theatre/ (accessed: 21 February 2019). The composer Tan Dun has offered another variant of 'orchestral theatre'. He used this phrase as a title for a multimedia orchestral tetralogy he composed in the 1990s, in which he incorporated elements of Chinese music and theatre. See: http://tandun.com/composition/orchestral-theatre-i-o/ (accessed: 20 April 2019).

${ }^{4}$ Masa Spaan uses the term 'synergistic concert dramaturgy' to refer to a contemporary mode of concert curation that is distinguished by the following determinants: 'collaborations with musicians who are willing, committed participants and able to communicate openly; substantive links to other genres, disciplines, or themes; the nature and potential of the venue; and, relatedly, the ways in which performances can be staged and/or choreographed'. Spaan, 'Curating Classical Music: Towards a Synergistic Concert Dramaturgy' in Dromey and Haferkorn, eds., The Classical Music Industry, p. 177. This article uses 'orchestral theatre' as a framing concept because the article focuses on collaborations between theatre-makers and musicians on stage productions as well as concerts.

${ }^{5}$ Violinist Nigel Kennedy, cellist Matthew Sharp, clarinettist Martin Fröst, the Gogmagogs (founded by Lucy Bailey and Nell Catchpole) and the Clod Ensemble are relevant in this context. The Bristol Proms, which held festivals from 2013-2015, has also pioneered unconventional, readily engaging, and technologically innovative approaches to performances of classical music.

6 Phyllis Hartnoll and Peter Found, 'Orchestra', in The Concise Oxford Companion to the Theatre (Oxford University Press, 1996; online version, 2003).

7 Ibid. See also John Spitzer and Neal Zaslaw, The Birth of the Orchestra: History of an Institution, 1650-1815 (Oxford: Oxford University Press, 2004), p. 343-60.

8 Ibid., v.

${ }^{9}$ Michael Pisani, 'Music for the Theatre: Style and Function in Incidental Music', in Kerry Powell, ed., The Cambridge Companion to Victorian and Edwardian Theatre (Cambridge: Cambridge University Press, 2004), p. 81. 
10 The phrase 'every good boy deserves favour' is a mnemonic for the note names of the lines of staff notation in the treble clef.

${ }^{11}$ For a discussion of Every Good Boy as a quasi-musical, see Mary Lo Lodge, 'Special Theatrical Event: Every Good Boy Deserves Favour', Studies in Musical Theatre 43, No. 1 (2009), p. 213-8.

12 Stoppard, Every Good Boy, p. 7.

${ }^{13}$ In the beginning of the play the situation is slightly different. The onstage orchestra is directed to mime playing their instruments. The audience cannot hear the musical performance in which Ivanov is ostensibly involved (as triangle player). After about a minute, 'very quietly, we begin to hear what Ivanov can hear - i.e., the orchestra becomes audible'. Ibid., p. 8. The audience is gradually ‘tuned into’ Ivanov's acoustic imaginary.

14 Ibid., p. vi.

15 Ibid., p. 34.

${ }^{16}$ Tom Stoppard and André Previn, Every Good Boy Deserves Favour: A Play for Actors and Orchestra (New York: RCA Red Seal, 1978) (LP liner notes).

17 Ibid.

${ }^{18}$ Ibid.

19 To clarify: there were many stagings of Every Good Boy around the world following its premiere. The 2009 NT production is of particular note as a reimagining of the work.

${ }^{20}$ Interview with Simon Over on November 1, 2018 at St John's Church, Waterloo.

${ }^{21}$ Interview with Tom Morris. While artistic director of the Battersea Arts Centre from 1995-2004, Morris oversaw two seasons of work aimed at de-formalising the presentation of classical music (BAC Opera and A Sharp Intake of Music). Morris later oversaw the Bristol Proms, directing a semi-staged version of Handel's Messiab in 2017.

${ }^{22}$ Interview with Felix Barrett at the University of Exeter on 23 January 2019.

${ }^{23}$ Michael Kirby, 'On Acting and Not-Acting', The Drama Review: TDR, 16, No. 1 (1962), p. 5.

24 Stoppard, Every Good Boy, p. 18.

${ }^{25}$ Morris remarked in an interview for this article: 'The conductor is clearly in some sort of position of power: whether you think they're a KGB general or a police chief ... or a mayor or Stalin wasn't something that we thought the audience would particularly question, but you do see it as an authoritative relationship. If we'd had more time, I would have got Simon [Over] ... to conduct the violence as well as the music. That would have developed the metaphor further'.

26 Ibid.

${ }^{27}$ Interview with Simon Over.

${ }^{28}$ Interview with Tom Morris.

${ }^{29}$ Interview with Simon Over.

${ }^{30}$ Ibid.

${ }^{31}$ Ibid.

32 Jonathan Miller first presented his staging of the Matthew Passion in 1993 (the NT was not involved). Bennett's Hymn was first performed at the Harrogate Festival in August 2001 and featured the Medici String Quartet.

${ }^{33}$ Email from James Murphy to the author. 
${ }^{34}$ Ibid. Amadeus was performed with a musical ensemble in a production staged at Wilton's Music Hall in London in 2006.

35 The programme for the 1979 NT production credits Jonty Harrison for 'Tape' and Christopher Kite for 'Fortepiano'.

${ }^{36}$ Matt Wolf, 'Salieri, Still Bested by Mozart', New York Times, 19 November 2016, p. 20.

${ }^{37}$ Ann Treneman, 'Musical Starlings Give Boy Wonder a Soaring Revival, The Times, 28 October 2016, p. 25.

${ }^{38}$ Simon Jenner, 'Amadeus: review', Fringe Review UK 2016, http://fringereview.co.uk/review/fringereview-

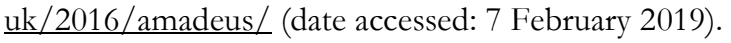

${ }^{39}$ Interview with Imogen Knight on 7 December 2018.

40 Ibid.

${ }^{41}$ Michael Kirby, 'On Acting and Not-Acting', p. 6.

42 Shaffer, Amadeus, p. 23.

${ }^{43}$ Interview with Imogen Knight.

${ }^{44}$ Michael Billington, 'Amadeus Review: Stunning Production Pits Salieri against God, Mozart and his own Orchestra', The Guardian, 27 October 2016, https://www.theguardian.com/stage/2016/oct/27/amadeus-reviewnational-michael-longhurst-lucian-msamati-salieri (accessed: 10 March 2019).

${ }^{45}$ Interview with Imogen Knight.

46 Shaffer, Amadeus, p. 101, 102.

47 Ibid., p. 13.

${ }^{48}$ Interview with Imogen Knight. The observation about Gillen's offhand remark is made from viewing a recording of the NT Live broadcast, dated 2 February 2017, held at the National Theatre Archive. Likening Mozart to a popstar was also part of the marketing campaign for the 1984 movie. See Marie Josephine Bennett, 'Shamadeus? Reconstructing Mozart: The Continuing Impact of Amadeus and Myths on Mozart Reception', in Jackie Raphael et al., eds., Disassembling the Celebrity Figure (Amsterdam: Rodopi, 2019), pp. 223-45.

${ }^{49}$ Gillen made this observation in a pre-show talk included as part of the NT Live broadcast of Amadeus on 2 February 2017 (recording held at the NT Archive).

${ }^{50}$ Transcription of comments made by Michael Longhurst in a pre-show talk included as part of the NT Live broadcast of Amadeus on 2 February 2017 (recording held at the NT Archive). Contrary to Longhurst's statement, Salieri's music is still performed and listened to today; indeed, there has been renewed interest in his music in recent decades.

51 Shaffer, Amadeus, p. 103.

${ }^{52}$ Compare with Sylvia Milo's play The Other Mozart, which premiered in 2014 and concerns Nannerl Mozart, Wolfgang's sister, who was also a musician.

${ }^{53}$ See Christina Scharff, 'Inequalities in the Classical Music Industry: The Role of Subjectivity in Constructions of the "Ideal" Classical Musician', in Dromey and Haferkorn, eds., The Classical Music Industry, p. 112-27.

54 The poster image prominently features Msamati as Salieri, suggesting that Msamati is the star of the show and that Salieri is the central character. Msamati stands in front of a wall on which an image of the historical Mozart (not Adam Gillen) has been plastered several times, like a billboard. Some of the reproductions of the Mozart image are smudged or partially erased. 
${ }^{55}$ Email from James Murphy.

${ }^{56}$ Interview with Matt Belcher on 2 November 2018 at St John's Church, Waterloo.

${ }^{57}$ The brochure is available online: https://issuu.com/southbanksinfonia/docs/concert diary 2017 -

digital single (accessed: 18 March 2019).

${ }^{58}$ Christopher Small, Musicking: The Meanings of Performing and Listening (Middletown: Wesleyan University Press, 1998).

${ }^{59}$ Simon Shaw-Miller, Eye bEar: The Visual in Music (Farnham: Ashgate, 2013), p. xiii.

${ }^{60}$ See also Nicholas Cook, 'Seeing Sound, Hearing the Body: Glenn Gould Plays Webern's Piano Variations', in Yael Kaduri, ed., The Oxford Handbook of Sound and Image in Western Art (Oxford: Oxford University Press, 2016), p. 124-

37.

${ }^{61}$ Peter Brook, The Empty Space (New York: Atheneum, 1968).

${ }^{62}$ Email from James Murphy.

${ }^{63}$ These questions are taken from a report on the 2017 \#ConcertLab series prepared by the SbS. Thanks to Matt Belcher for providing me with this report.

${ }^{64}$ Ibid, p. 8

${ }^{65} \mathrm{Ibid}$, p. 7.

${ }^{66}$ Interview with Matt Belcher.

${ }^{67}$ Ibid.

${ }^{68}$ Ibid.

${ }^{69}$ Interview with Imogen Knight.

${ }^{70}$ These observations derive from a recording of the performance made by the SbS. Thanks to Matt Belcher for making this recording available to me.

${ }^{71}$ Interview with Imogen Knight.

72 Anna Meredith's tweet may be viewed here: https://twitter.com/AnnaHMeredith/status/873163776996122629 (accessed: 18 March 2019).

${ }^{73}$ Interview with Matt Belcher.

${ }^{74}$ Interview with Imogen Knight.

${ }^{75}$ Ibid.

${ }^{76}$ Interview with Matt Belcher.

${ }^{77}$ Ibid.

${ }^{78}$ See Julia Haferkorn, 'Dancing to Another Tune: Classical Music in Nightclubs and Other Non-Traditional Venues', in Dromey and Haferkorn, eds., The Classical Music Industry, p. 148-71.

${ }^{79}$ Interview with Felix Barrett. 